\title{
Blood Pressure Recording in Children
}

\author{
M. LONG*, J. R. DUNLOPt, and W. W. HOLLAND \\ From the Department of Clinical Epidemiology and Social Medicine, St. Thomas's Hospital Medical School, London
}

Long, M., Dunlop, J. R., and Holland, W. W. (1971). Archives of Disease in Childhood, 46, 636. Blood pressure recording in children. Blood pressure levels for 148 children aged 0-14 years were recorded. Two different methods of measurement (the standard sphygmomanometer and the random-zero machine) and two cuffs of varying size were used on each child. Measurements of arm size and pulse rate were taken, and an assessment was made of the emotional state of each child: no association was found between these factors and the recorded measurement of blood pressure. The experiment does however show that: (1) the effect of cuff size can be minimized by using the largest cuff that will fit the child, and then applying a standard correction to the measurement taken; and (2) the random-zero machine is a preferable method of measurement as it reduces observer bias, though measurements taken with a standard and a random-zero machine are not directly comparable.

The many factors that appear to affect the validity of indirect blood pressure readings in both children and adults have now been the subject of investigation for more than 30 years. In studies of direct and indirect readings of blood pressure in infants and older children, Woodbury, Robinow, and Hamilton (1938) and Robinow et al. (1939) showed that, when arbitrarily selected cuffs were used, the accuracy of indirect readings was greatly affected by the relation between arm size (as determined by arm circumference) and the size of the blood pressure cuff. They concluded that the smaller the arm, the narrower the cuff should be, and that, for the newborn, cuffs wider than 2.5 $\mathrm{cm}$ would produce artificially low readings. In a study of 51 adults, Ragan and Bordley (1941) attributed differences between direct and indirect blood pressure measurements to the influence of arm circumference measurements. It should, however, be noted that some of their subjects were patients with aortic incompetence. The authors also compared the relative accuracy of the standard American $13 \mathrm{~cm}$ cuff with the $20 \mathrm{~cm}$ cuff, finding that the wider cuff gave more 'accurate' readings where the arm circumference was large, though its use in 'average' subjects produced artificially low readings.

\footnotetext{
Received 5 April 1971.

^Now Mrs. M. Bone. Present address: 1 Westbourne Crescent, Highfield, Southampton.

tPresent address: Computer Centre, Chelsea College, Pulton Place Annexe, Fulham Road, London S.W.6.
}

In a more recent study Holland and Humerfelt (1964) compared direct and indirect readings in 47 adults, using a method of recording indirect blood pressure free from observer bias (Holland, 1963) and a standard $12 \times 24 \mathrm{~cm}$ cuff. In an assessment of the influence of arm size, skinfold thickness, and weight on the relation between differences in direct and indirect readings, differences were found to be greater as the direct level of blood pressure increased. There was a small correlation between arm circumference and level of indirect arterial pressure, but, as this was largely contributed by the effect of weight, the authors suggested that in adults no allowance need be made in adjustments of levels of blood pressure. This conclusion is supported by a study of indirect blood pressure measurements in about 5000 men aged 15-69 (Khosla and Lowe, 1965), in which readings were found to be affected by the relative weight of the individual, but not by the arm circumference per se.

Karvonen, Telivuo, and Järvinen (1964) drew attention to another factor that could influence blood pressure readings. In a comparison of direct and indirect readings in 53 subjects, they found that too short a cuff bladder may, like too narrow a cuff, produce artificially high readings. Once this was taken into account, arm circumference had no influence on levels of blood pressure. Similarly, King (1967) and Simpson et al. (1965) found that low indirect pressure readings resulted from the use of cuffs that were wider and longer 
than standard. In a study of the effect of simulated obesity as determined by arm circumference measurement, King (1967) found that too short a blood pressure bladder produced artificially high readings, but concluded that, once the cuff had encircled the arm, the effect of the cuff length on the readings was minimal. He stressed the importance of these findings for paediatric studies.

In studies of infants, Lang and Hilber (1969) used an electric method of recording indirect blood pressure readings similar to electric impedance plethysmography to compare readings obtained by cuffs 2,4 , and $6 \mathrm{~cm}$ wide. He concluded that the $4 \mathrm{~cm}$ cuff produced the most accurate readings and the $6 \mathrm{~cm}$ cuff was often too large for the subject. Unfortunately, most paediatric studies of blood pressure recordings have so far been concerned only with techniques of measurement, of which the most commonly used are palpation (Holland and Young, 1956), electrical impedance plethysmography (Lang and Hilber, 1969), and the flush method. Few, if any, paediatric studies have systematically considered all factors that could contribute to variation in blood pressure readings, though Rose, Holland, and Crowley (1964) have summarized possible sources of error in adults, and these are, of course, equally applicable to children. In view of the many sources of possible error in recording blood pressure in children, readings may often have minimal clinical value, and many may even be misleading. This investigation, therefore, attempts to find a method of measuring blood pressure in children, which will enable valid comparisons to be made between children independent of their age, size, or the cuff size used.

\section{Material and Methods}

148 children from paediatric wards and outpatient clinics were examined by 5 observers over a period of 2 months. On each patient, blood pressure measurements were taken using a standard and a random-zero sphygmomanometer (Wright and Dore, 1970), a modification of the Garrow Zero Muddler, which is designed to reduce observer bias (Garrow, 1963). The observers were carefully trained in the use of both machines, and the observer technique was standardized by listening to blood pressure recordings (Rose, 1965). Systolic pressure, diastolic I (Korotkow 4th phase) and diastolic II pressure (Korotkow 5th phase) were recorded on each occasion.

Each child was measured with two cuffs of differing size. Five standard cuffs, manufactured by Accoson but with extended velcro fastenings, were used: cuff $1-4$ in. $\times 1$ in. $(10 \times 2.54 \mathrm{~cm})$; cuff $2-4$ in. $\times 2$ in. $(10 \times 5.08 \mathrm{~cm})$; cuff $3-6$ in. $\times 3$ in. $(15.24 \times$ $7.62 \mathrm{~cm})$; cuff $4-7 \frac{1}{2}$ in. $\times 4$ in. $(19.05 \times 10.16 \mathrm{~cm})$; and cuff 5-9 in. $\times 5$ in. $(22.86 \times 12.70 \mathrm{~cm})$. The children were divided into four age groups, $0-1,1-4$, 5-9, and 10-14 years. In the three youngest age groups two cuffs were used for each group; in the oldest age group three cuffs were used, as there was greater variation in the size of the older children (Table I).

TABLE I

Number of Children Tested in Each Age Group and Cuff Sizes Used

\begin{tabular}{c|c|c}
\hline $\begin{array}{c}\text { Age } \\
(y r)\end{array}$ & $\begin{array}{c}\text { Cuff } \\
\text { Sizes Used }\end{array}$ & $\begin{array}{c}\text { No. of } \\
\text { Children Measured }\end{array}$ \\
\hline $0-1$ & 1,2 & 16 \\
$1-4$ & 2,3 & 32 \\
$5-9$ & 3,4 & 40 \\
$10-14$ & 3,4 & 20 \\
$10-14$ & 3,5 & 20 \\
$10-14$ & 4,5 & 20 \\
\hline & Total & 148 \\
\hline
\end{tabular}

The following arm measurements were taken on each child: (1) upper arm length (in $\mathrm{cm}$ ) measured from the acromion process to the olecranon using a flexible steel tape; (2) arm circumference (in $\mathrm{cm}$ ) measured at the mid-point between the acromion and the olecranon; and (3) skinfold thickness over the triceps mucles, at the same level as arm circumference, using the Harpenden skinfold thickness caliper (Edwards et al., 1955).

All readings were taken on the left arm with the child seated. The pulse rate and emotional state of the child were also recorded during the examination. Two observers were present, one recording results while the other either entertained or held the child. The order in which the cuffs and methods of recording were used was randomly allocated. If a child did not co-operate for any one of the readings, the results for that child were not included in the analyses comparing cuff sizes and recorded measurements (Tables II, III, and VI).

\section{Results}

Influence of cuff size. Within each age group the level of blood pressure recorded was higher when the smaller cuff was used. This was found true for both systolic and diastolic pressures. Using cuffs 1 or 2, it appeared that levels of blood pressure were higher in children aged less than 1 year than in children aged 1-4 years (Table II).

For each group of children on which the five different combinations of cuffs were used, and for each of the three phases of blood pressure, the average difference between the readings with the smaller and larger cuff was regressed on arm length, arm circumference, and skinfold thickness, separately and in combination. Surprisingly, not even one of these 60 regressions was significant at the $5 \%$ level. As no association could be found 
TABLE II

Mean Blood Pressure According to Cuff Size and Phase

\begin{tabular}{|c|c|c|c|c|c|c|c|c|}
\hline \multirow{2}{*}{$\begin{array}{c}\text { Age } \\
\text { Group } \\
\text { (yr) }\end{array}$} & \multirow{2}{*}{$\begin{array}{l}\text { Cuff } \\
\text { Size } \\
\text { Used }\end{array}$} & \multicolumn{2}{|c|}{$\begin{array}{l}\text { Systolic Pressure } \\
\text { (mmHg) }\end{array}$} & \multicolumn{2}{|c|}{$\begin{array}{c}\text { Diastolic I Pressure } \\
(\mathrm{mmHg})\end{array}$} & \multicolumn{2}{|c|}{$\begin{array}{l}\text { Diastolic II Pressure } \\
(\mathrm{mmHg})\end{array}$} & \multirow{2}{*}{$\begin{array}{c}\text { No. } \\
\text { of } \\
\text { Children }\end{array}$} \\
\hline & & $\begin{array}{l}\text { Smaller } \\
\text { Cuff }\end{array}$ & $\begin{array}{l}\text { Larger } \\
\text { Cuff }\end{array}$ & $\begin{array}{l}\text { Smaller } \\
\text { Cuff }\end{array}$ & $\begin{array}{l}\text { Larger } \\
\text { Cuff }\end{array}$ & $\begin{array}{l}\text { Smaller } \\
\text { Cuff }\end{array}$ & $\begin{array}{l}\text { Larger } \\
\text { Cuff }\end{array}$ & \\
\hline $\begin{array}{c}0-1 \\
1-4 \\
5-9 \\
10-14 \\
10-14 \\
10-14\end{array}$ & $\begin{array}{l}1,2 \\
2,3 \\
3,4 \\
3,4 \\
4,5 \\
3,5\end{array}$ & $\begin{array}{l}134 \\
120 \\
104 \\
111 \\
113 \\
110\end{array}$ & $\begin{array}{l}114 \\
101 \\
100 \\
106 \\
108 \\
100\end{array}$ & $\begin{array}{l}91 \\
81 \\
69 \\
76 \\
77 \\
77\end{array}$ & $\begin{array}{l}73 \\
64 \\
65 \\
71 \\
73 \\
71\end{array}$ & $\begin{array}{l}84 \\
72 \\
61 \\
70 \\
70 \\
71\end{array}$ & $\begin{array}{l}68 \\
56 \\
58 \\
64 \\
68 \\
63\end{array}$ & $\begin{array}{l}15 \\
30 \\
38 \\
20 \\
20 \\
20\end{array}$ \\
\hline
\end{tabular}

$\star 5$ children who cried or struggled have been excluded from this analysis.

TABLE III

Mean Levels of Blood Pressure According to Method of Measurement and Cuff Size

\begin{tabular}{|c|c|c|c|c|c|c|c|}
\hline \multirow{2}{*}{$\begin{array}{c}\text { Blood } \\
\text { Pressure }\end{array}$} & \multirow{2}{*}{ Machine } & \multicolumn{5}{|c|}{ Cuff } & \multirow{2}{*}{$\begin{array}{l}\text { Weighted } \\
\text { Means }\end{array}$} \\
\hline & & 1 & 2 & 3 & 4 & 5 & \\
\hline $\begin{array}{l}\text { Systolic } \\
\text { Diastolic I } \\
\text { Diastolic II } \\
\star \text { No. of children }\end{array}$ & $\begin{array}{l}\text { Zero-Muddler } \\
\text { Normal } \\
\text { Zero-Muddler } \\
\text { Normal } \\
\text { Zero-Muddler } \\
\text { Normal }\end{array}$ & $\begin{array}{r}131 \\
136 \\
89 \\
92 \\
82 \\
84 \\
15\end{array}$ & $\begin{array}{r}119 \\
117 \\
79 \\
78 \\
72 \\
70 \\
45\end{array}$ & $\begin{array}{r}104 \\
107 \\
69 \\
72 \\
62 \\
65 \\
108\end{array}$ & $\begin{array}{r}103 \\
106 \\
67 \\
72 \\
60 \\
65 \\
78\end{array}$ & $\begin{array}{r}103 \\
104 \\
70 \\
73 \\
64 \\
68 \\
40\end{array}$ & $\begin{array}{r}107 \cdot 3 \\
109 \cdot 5 \\
71 \cdot 5 \\
74 \cdot 0 \\
64 \cdot 1 \\
66 \cdot 8\end{array}$ \\
\hline
\end{tabular}

* 5 children who cried or struggled have been excluded from the analysis.

TABLE IV

Frequency of Each Terminal Digit According to Fieldworker and Machine

\begin{tabular}{|c|c|c|c|c|c|c|c|}
\hline \multirow{2}{*}{$\begin{array}{l}\text { Field- } \\
\text { worker }\end{array}$} & \multicolumn{5}{|c|}{ Terminal Digit } & \multirow{2}{*}{ Total } & \multirow{2}{*}{$\chi_{4}^{2}$} \\
\hline & 0 & 2 & 4 & 6 & 8 & & \\
\hline $\begin{array}{c}\text { Standard } \\
\text { Method } \\
\text { A } \\
\text { B } \\
\text { C } \\
\text { D } \\
\text { E } \\
\text { Zero } \\
\text { Muddler } \\
\text { A } \\
\text { B } \\
\text { C } \\
\text { D } \\
\text { E }\end{array}$ & $\begin{array}{l}97 \\
38 \\
35 \\
49 \\
96\end{array}$ & $\begin{array}{l}27 \\
28 \\
17 \\
11 \\
19\end{array}$ & $\begin{array}{l}28 \\
42 \\
15 \\
11 \\
20\end{array}$ & $\begin{array}{r}26 \\
62 \\
18 \\
8 \\
89 \\
49\end{array}$ & $\begin{array}{l}38 \\
36 \\
23 \\
29 \\
30\end{array}$ & $\begin{array}{l}216 \\
216 \\
108 \\
108 \\
214\end{array}$ & $\begin{array}{l}85 \cdot 90 \ddagger \\
10 \cdot 67 \\
12 \cdot 00 \ddagger \\
56 \cdot 26 \ddagger \\
96 \cdot 22 \ddagger\end{array}$ \\
\hline
\end{tabular}

between the variables and the different measurements, with different cuffs, differences in arm measurements were ignored in subsequent analyses.
Influence of emotional state and pulse rate. It was found impossible to assess the influence of the emotional state of the child on the blood pressure recorded, as most ( $80 \%$ ) of the children were placid at the time of measurement. An analysis of covariance was carried out on the readings of 56 children measured with cuffs 3 and 4, with the children, cuff, and machine as factors, and the pulse rate as a covariate. However, the regression coefficient was not significant in any of the three phases, indicating that there was no correlation between pulse rate and level of blood pressure.

Methods of recording blood pressure. Theoretically the two blood pressure recording machines should give the same readings. We found that, however, in almost all cases levels of pressure were lower with the random zero machine (Table III). The difference between the two machines is about $2 \mathrm{mmHg}$. This was also found by Evans and Prior (1970).

This variation is difficult to explain. It cannot be due to the order of measurement, nor to differences in perception of end point. It is possibly attributable to small differences in the machines 
used, or to the fact that, when the level of mercury was between two marks, observers were instructed to read to the nearest $2 \mathrm{~mm}$ below. When the Garrow machine was used, this procedure was, of course, followed twice, once when taking the reading and once when subtracting the 'zero correction'. This may account for at least $1 \mathrm{~mm}$ of the difference.

The Garrow machine is designed to reduce observer variability. One measure of this is the frequency of recording terminal digits (digit preference). All five observers showed a marked digit preference when using the normal machine, but with the Garrow machine terminal digit preference was eliminated in three observers and noticeably reduced in the other two (Table IV).

\section{Discussion}

This investigation clearly shows the difficulties involved in choosing the right cuff size for the measurement of blood pressure in children. Factors such as upper arm length, arm circumference, and skinfold thickness appeared to have little influence on the level of blood pressure recorded, a finding that replicates those of similar investigations on adults (Holland and Humerfelt, 1964). In addition, pulse rate did not appear to have an effect on the recorded level.

However, differences were found in the same child when cuffs of differing size were used, smaller cuffs giving consistently higher readings. One possible explanation for this is that the excess pressure generated by a small cuff is dissipated into the surrounding flesh; this effect is of course lessened as wider cuffs are used. If, therefore, one assumes that every reading with a small cuff has an intrinsic bias, it may be possible to estimate the extent of this bias, and thus to obtain comparable readings in the same child when using a different cuff. The extent of this bias may be calculated by regressing the blood pressure readings recorded by two different cuffs and the size of cuff within each age group (see Appendix for method). Table V gives the results of such an analysis and shows the

TABLE V

Correction for Smaller Cuffs to Obtain Readings Comparable to Those Given Using a Large Cuff

\begin{tabular}{l|c|c|c|c}
\hline \multicolumn{1}{c|}{ Cuff Sizes } & Cuff & Systolic & Diastolic I & Diastolic II \\
\cline { 1 - 2 } 4 in. $\times 1$ in. & 1 & $44 \cdot 8$ & $39 \cdot 8$ & $36 \cdot 7$ \\
4 in. $\times 2$ in. & 2 & 27.5 & $23 \cdot 4$ & $23 \cdot 1$ \\
6 in. $\times 3$ in. & 3 & $9 \cdot 7$ & $6 \cdot 9$ & $7 \cdot 2$ \\
$7 \frac{1}{2}$ in. $\times 4$ in. & 4 & $5 \cdot 8$ & 3.0 & $2 \cdot 5$ \\
9 in. $\times 5$ in. & 5 & 0.0 & 0.0 & 0.0 \\
\hline
\end{tabular}

Example (1) Systolic blood pressure of small child $=130 \mathrm{mmHg}$. Cuff 1 used.

Corrected systolic blood pressure $=130-44 \cdot 8=$ $85 \cdot 2 \mathrm{mmHg}$.

(2) Diastolic blood pressure in toddler $=70 \mathrm{mmHg}$. Cuff 3 used.

Corrected diastolic blood pressure $=70-6.9=$ $63.1 \mathrm{mmHg}$.

(3) Diastolic 2 blood pressure in teenager $=70 \mathrm{mmHg}$. Cuff 4 used.

Corrected diastolic 2 pressure $=70-2 \cdot 5=67 \cdot 5$ $\mathrm{mmHg}$.

corrections which need to be applied to readings obtained by a small cuff in order to obtain readings comparable to those given using a large cuff. The assumption underlying the use of this technique is that a large cuff, i.e. cuff 5, has no bias, and it will be seen that the correction necessary when the smallest cuff is used is considerable, but is progressively reduced with increase in the size of cuff.

If one then applies these correction factors to the mean blood pressure readings for each age group, levels recorded by two cuffs of different size are very similar; one also finds a rise in blood pressure readings with age (Table VI). These findings would be expected. We therefore suggest that

TABLE VI

Adjusted Mean Blood Pressure According to Cuff Size

\begin{tabular}{|c|c|c|c|c|c|c|c|c|}
\hline \multirow{2}{*}{$\begin{array}{c}\text { Age } \\
\text { Group } \\
\text { (yr) }\end{array}$} & \multirow{2}{*}{$\begin{array}{c}\text { Cuff } \\
\text { Size } \\
\text { Used }\end{array}$} & \multicolumn{2}{|c|}{$\begin{array}{l}\text { Systolic Pressure } \\
\text { (mmHg) }\end{array}$} & \multicolumn{2}{|c|}{$\begin{array}{l}\text { Diastolic I Pressure } \\
(\mathrm{mmHg})\end{array}$} & \multicolumn{2}{|c|}{$\begin{array}{l}\text { Diastolic II Pressure } \\
(\mathrm{mmHg})\end{array}$} & \multirow{2}{*}{$\begin{array}{c}\text { No. } \\
\text { of } \\
\text { Children }\end{array}$} \\
\hline & & $\begin{array}{c}\text { Smaller } \\
\text { Cuff }\end{array}$ & $\begin{array}{l}\text { Larger } \\
\text { Cuff }\end{array}$ & $\begin{array}{l}\text { Smaller } \\
\text { Cuff }\end{array}$ & $\begin{array}{l}\text { Larger } \\
\text { Cuff }\end{array}$ & $\begin{array}{c}\text { Smaller } \\
\text { Cuff }\end{array}$ & $\begin{array}{l}\text { Larger } \\
\text { Cuff }\end{array}$ & \\
\hline $\begin{array}{c}0-1 \\
1-4 \\
5-9 \\
10-14 \\
10-14 \\
10-14\end{array}$ & $\begin{array}{l}1,2 \\
2,3 \\
3,4 \\
3,4 \\
4,5 \\
3,5\end{array}$ & \begin{tabular}{r|}
89 \\
92 \\
94 \\
101 \\
107 \\
100
\end{tabular} & \begin{tabular}{|r|r|}
86 \\
91 \\
94 \\
100 \\
108 \\
100
\end{tabular} & $\begin{array}{l}51 \\
58 \\
62 \\
69 \\
74 \\
70\end{array}$ & $\begin{array}{l}50 \\
57 \\
62 \\
68 \\
73 \\
71\end{array}$ & $\begin{array}{l}47 \\
49 \\
54 \\
63 \\
67 \\
64\end{array}$ & $\begin{array}{l}45 \\
49 \\
55 \\
61 \\
68 \\
63\end{array}$ & $\begin{array}{l}15 \\
30 \\
38 \\
20 \\
20 \\
20\end{array}$ \\
\hline
\end{tabular}

$\star 5$ children who cried or struggled have been excluded from the analysis. 
blood pressure in children should be measured by using the largest cuff that will comfortably encircle the arm, then applying the appropriate correction factor as indicated. This will enable valid comparisons to be made for the same child and with other children. It is recognized that we are assuming that indirect blood pressure measured with a cuff is a true reflection of the direct measurement. Other studies, e.g. Holland and Humerfelt (1964), have shown that though the absolute levels of pressure recorded by indirect and direct methods of measurement differ there is a high degree of correlation between them ( $n=0.95$ for systolic pressure). Furthermore in clinical practice one is interested not so much in an absolute as a relative level. It is necessary to know whether blood pressure has changed in a child over time, and the relative size of this change rather than the absolute values at any one point in time. Similarly it is important to know whether the level of blood pressure in one child differs from that of another. The 'true' levels are not as important as long as the distribution of these levels of indirect pressure in children are known. This method enables corrections to be made to allow comparisons between children of different sizes and in the same child at different ages.

The advantages of the random-zero machine over the standard sphygmomanometer are seen in the reduction of terminal digit preference. It is, however, also seen that there are differences in the mean levels of blood pressure recorded by the standard sphygmomanometer and the randomzero machine. Again, therefore, appropriate corrections should be applied when making comparisons between measurements recorded by the two types of machine.

We thank Dr. I. Z. Roth for suggesting the method of correction for the cuff size; Dr. A. E. Bennett for his help in the design of the study; and Dr. B. D. R. Wilson and the late Dr. D. Cottom for permission to undertake these measurements on patients under their care. The study was supported in part by grants from the Department of Health and Social Security.

\section{REFERENCES}

Edwards, D. A. W., Hammond, W. H., Healy, M. J. R., Tanner, J. M., and Whitehouse, R. H. (1955). Design and accuracy of calipers for measuring subcutaneous tissue thickness. British fournal of Nutrition, 8, 133.

Evans, J. G., and Prior, I. A. M. (1970). Experience with the random-zero sphygmomanometer. British fournal of Preventive and Social Medicine, 24, 10.

Garrow, J. S. (1963). Zero-muddler for unprejudiced sphygmomanometry. Lancet, 2, 1205.

Holland, W. W. (1963). The reduction of observer variability in the measurement of blood pressure. In Epidemiology:
Reports on Research and Teaching, 1962, p. 271. Ed. by J. Pemberton. Oxford University Press, London.

Holland, W. W., and Humerfelt, S. (1964). Measurement of blood-pressure: comparison of intra-arterial and cuff values. British Medical fournal, 2, 1241.

Holland, W. W., and Young, I. M. (1956). Neonatal blood pressure in relation to maturity, mode of delivery, and condition at birth. British Medical fournal, 2, 1331.

Karvonen, M. J., Telivuo, L. J., and Järvinen, E. J. K. (1964). Sphygmomanometer cuff size and the accuracy of indirect measurement of blood pressure. American fournal of Cardio$\log y, 13,688$.

Khosla, T., and Lowe, C. R. (1965). Arterial pressure and arm circumference. British fournal of Preventive and Social Medicine, 19, 159.

King, G. E. (1967). Errors in clinical measurement of blood pressure in obesity. Clinical Science, 32, 233.

Lang, V. O., and Hilber, H. M., Jr. (1969). Zur Blutdruckmessung im Săuglingsalter. I. Der Einfluss verschiedener manschettenbreiten auf den gemessenen Blutdruckwert. Zeitschrift für Kinderheilkunde, 105, 156.

Ragan, C., and Bordley, J., III (1941). The accuracy of clinical measurements of arterial blood pressure. Bulletin of the fohns Hopkins Hospital, 69, 504.

Robinow, M., Hamilton, W. F., Woodbury, R. A., and Volpitto, P. P. (1939). Accuracy of clinical determination of blood pressure in children, with values under normal and abnormal conditions. American fournal of Diseases of Children, 58, 102.

Rose, G. A. (1965). Standardization of observers in blood-pressure measurements. Lancet, 1, 673.

Rose, G. A., Holland, W. W., and Crowley, E. A. (1964). A sphygmomanometer for epidemiologists. Lancet, 1, 296.

Simpson, J. A., Jamieson, G., Dickhaus, D. W., and Grover, R. F. (1965). Effect of size of cuff bladder on accuracy of measurement of indirect blood pressure. American Heart fournal, 70, 208.

Woodbury, R. A., Robinow, M., and Hamilton, W. F. (1938). Blood pressure studies on infants. American fournal of Physiology, 122, 472.

Wright, B. M., and Dore, C. F. (1970). A random-zero sphygmomanometer. Lancet, 1, 337.

\section{Appendix}

By the method of maximum likelihood, the following model was fitted to the readings of systolic blood pressure $\left(y_{i i}\right)$ :

$\mathrm{y}_{\mathrm{ij}}=\mu \mathrm{y}+\mathrm{C}_{\mathrm{i}}+\mathrm{M}_{\mathrm{j}}+\mathrm{I}_{\mathrm{ij}}+\emptyset_{1} \mathrm{P}_{1}(\mathrm{z})+\emptyset_{2} \mathrm{P}_{2}(\mathrm{z})+$ $\emptyset_{3} \mathbf{P}_{3}(\mathrm{z})+\emptyset_{4} \mathbf{P}_{4}(\mathrm{z})+\mathrm{e}_{\mathrm{ij}}$

where $y$ represents the systolic value,

$C_{i}(i=1,2,3 \ldots 144)$ represents the child effect,

$M_{j}(j=1,2)$ represents the machine effect,

$I_{i j}$ represents the interaction between child and machine, $z(z=1,2,3,4,5)$ is the cuff number,

$\emptyset_{i}(i=1,2,3,4)$ are the coefficients corresponding to the orthogonal polynomials

$P(z)$ and $e_{i j}$ represent the random variation, assumed normally distributed with zero mean.

It should be noted (see page 638) that the numbers of the cuffs are proportional to their widths.

Having estimated the $\emptyset_{i}$ and $A_{x}$, where

$$
A_{\mathbf{x}}=\sum \hat{\emptyset}_{\mathrm{i}} \mathrm{P}_{\mathbf{i}}(\mathbf{x}) \quad(\mathbf{x}=1,2,3,4,5)
$$

the adjustment relative to cuff 5 for the first four cuffs was determined by subtracting $A_{6}$ from $A_{i}(i=1,2,3,4)$.

The analysis was repeated for the diastolic readings.

Correspondence to Professor W. W. Holland, St. Thomas's Hospital Medical School, London S.E.1. 